Article

\title{
Eutypenoids A-C: Novel Pimarane Diterpenoids from the Arctic Fungus Eutypella sp. D-1
}

\author{
Liu-Qiang Zhang ${ }^{1,+}$, Xiao-Chong Chen ${ }^{1,+}$, Zhao-Qiang Chen ${ }^{2}$, Gui-Min Wang ${ }^{2}$, Shi-Guo Zhu ${ }^{1}$, \\ Yi-Fu Yang ${ }^{1}$, Kai-Xian Chen ${ }^{1,2}$, Xiao-Yu Liu ${ }^{3, *}$ and Yi-Ming Li ${ }^{1, *}$ \\ 1 School of Pharmacy, Shanghai University of Traditional Chinese Medicine, 1200 Cailun Road, \\ Shanghai 201203, China; 04100217@163.com (L.-Q.Z.); chen7673@163.com (X.-C.C.); \\ jusco105@163.com (S.-G.Z.); yangyifu@mail.shcnc.ac.cn (Y.-F.Y); kxchen@simm.ac.cn (K.-X.C.) \\ 2 Shanghai Institute of Medica, Chinese Academy of Sciences, 555 Zuchongzhi Road, Shanghai 201203, China; \\ zqchen@simm.ac.cn (Z.-Q.C.); gmwang@simm.ac.cn (G.-M.W.) \\ 3 Department of Biochemistry and Molecular Biology, Second Military Medical University, 800 Xiangyin Road, \\ Shanghai 200433, China \\ * Correspondence: biolxy@163.com (X.-Y.L.); ymli@shutcm.edu.cn (Y.-M.L.); Tel.: +86-21-8187-0972 (X.-Y.L.); \\ +86-21-5132-2191 (Y.-M.L.); Fax: +86-21-6533-4344 (X.-Y.L.); +86-21-5132-2192 (Y.-M.L.) \\ + These authors contributed equally to this work.
}

Academic Editor: Vassilios Roussis

Received: 14 January 2016; Accepted: 15 February 2016; Published: 7 March 2016

\begin{abstract}
Eutypenoids A-C (1-3), pimarane diterpenoid alkaloid and two ring A rearranged pimarane diterpenoids, were isolated from the culture of Eutypella sp. D-1 obtained from high-latitude soil of the Arctic. Their structures, including absolute configurations, were authenticated on the basis of the mass spectroscopy (MS), nuclear magnetic resonance (NMR), X-ray crystallography, and electronic circular dichroism (ECD) analysis. The immunosuppressive effects of eutypenoids A-C (1-3) were studied using a ConA-induced splenocyte proliferation model, which suggested that 2 exhibited potent immunosuppressive activities.
\end{abstract}

Keywords: eutypenoid; novel pimarane diterpenes; Eutypella; Arctic fungi; immunosuppressive effect

\section{Introduction}

Marine-sourced fungi are, increasingly, a rich source of novel and bioactive compounds [1-3], but natural products from Arctic fungi are rarely studied. Arctic fungi are abundant and functionally important in the Arctic, where they drive mineral and energy cycles, and influence the occurrence of other organisms as mutualists, decomposers, and pathogens [4]. Meanwhile, Arctic fungi living in low temperatures, strong ultraviolet radiation, low nutrition, etc., might have evolved specific physiological and biochemical pathways to produce structurally novel and biological active metabolites, which can provide the opportunity for the discovery of new natural medicines.

Eutypella (Diatrypaceae) species, from the South Sea in China and Thailand, have been widely investigated in recent years. Most of metabolites, including pimarane diterpenoids, cytochalasin derivatives, $\gamma$-lactones, sesquiterpenoids, polyketides, and cytosporin-related compounds, display moderate or significant cytotoxic and antimicrobial activities [5-13]. However, no such study has been carried out on Eutypella species from the Polar region. Eutypella sp. D-1 was isolated from high-latitude soil of the Arctic. Previously, we have reported six pimarane diterpenoids and four tyrosine-derived cytochalasins from the culture of E. sp. D-1 [14-16]. In the current study on the crude extract of $E$. sp. D-1, we reported the isolation, structure elucidation, and immunosuppressive effects of three novel 
pimarane diterpenoids (1-3) (Figure 1), each of which possesses a novel structure type of diterpenoid, respectively. Further, these compounds were evaluated for their immunosuppressive effects.

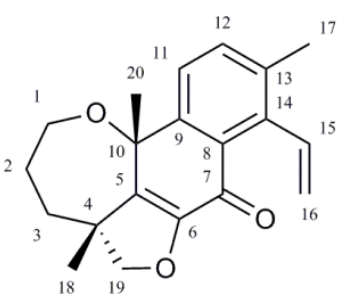

1

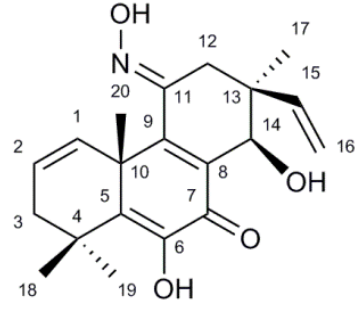

2

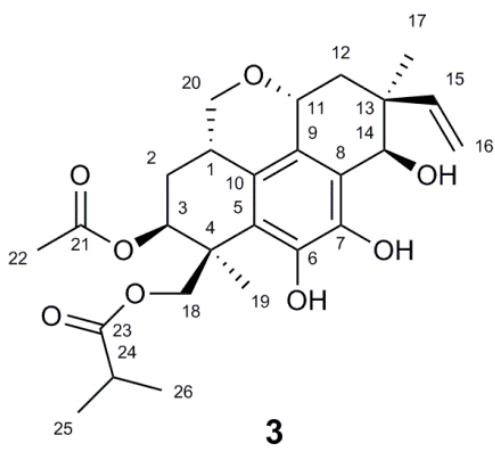

3

Figure 1. Structures of compounds 1-3.

\section{Results and Discussion}

Under bioassay guidance, the chemical constituents of E. sp. D-1 have been extensively investigated further. In this paper, three new novel rearranged pimarane diterpenoids (1-3) were isolated from the EtOAc extract of its culture broth.

Eutypenoid A (1) was obtained as colorless needle crystals (EtOH). Its molecular formula $\mathrm{C}_{20} \mathrm{H}_{22} \mathrm{O}_{3}$ was determined on the basis of the high-resolution electron impact mass spectrometry (HREIMS) at $m / z 310.1570\left[\mathrm{M}^{+}\right.$] (calcd. 310.1569), corresponding to ten degrees of unsaturation. The ${ }^{1} \mathrm{H}$ NMR spectrum of 1 showed a terminal vinyl group $(\delta 5.06, \mathrm{~d}, J=18.0 \mathrm{~Hz}, 5.49, \mathrm{~d}, J=11.5 \mathrm{~Hz}$, $7.19, \mathrm{dd}, J=18.0,11.5 \mathrm{~Hz})$, two aromatic protons $(\delta 7.43, \mathrm{~d}, J=8.0 \mathrm{~Hz}, 7.54, \mathrm{~d}, J=8.0 \mathrm{~Hz})$, and three methyl groups at $\delta 1.47,1.60,2.37$ (each $3 \mathrm{H}, \mathrm{s}$ ). The ${ }^{13} \mathrm{C}$ NMR spectrum showed 20 carbon resonances, which were assigned by distortionless enhancement by polarization transfer (DEPT) and heteronuclear single quantum coherence (HSQC) spectra to one lactone carbonyl carbon, ten olefinic carbons occupied six degrees of unsaturation. These data suggested that $\mathbf{1}$ is a diterpenoid possessing a tetracyclic ring system. Further structural information was derived by $2 \mathrm{D}$ NMR analysis, including HSQC, ${ }^{1} \mathrm{H}^{1} \mathrm{H}$ correlation spectroscopy (COSY), and HMBC (Figure 2). Correlations were detected for $\mathrm{H}-1 / \mathrm{H}-2 / \mathrm{H}-3$ using COSY. The long range HMBC correlations of H-1/C-3 ( $\delta 40.6)$ and C-10 ( $\delta 76.9) ; \mathrm{H}-2 / \mathrm{C}-4(\delta 49.8)$; $\mathrm{H}-3 / \mathrm{C}-1$ ( $\delta 67.2), \mathrm{C}-5\left(\delta\right.$ 138.6); $\mathrm{H}_{3}-20 / \mathrm{C}-5$ corroborated the oxepane skeleton of ring A. The furan ring was established using the $\mathrm{HMBC}$ correlations of $\mathrm{H}-19 / \mathrm{C}-3, \mathrm{C}-5, \mathrm{C}-18$, and C-6. Additionally, the ${ }^{1} \mathrm{H}-{ }^{1} \mathrm{H}$ COSY correlations from $\mathrm{H}-11$ to $\mathrm{H}-12$ and the HMBC correlations from $\mathrm{H}-11 / \mathrm{C}-7, \mathrm{C}-8, \mathrm{C}-10$ and $\mathrm{C}-13 ; \mathrm{H}-12 / \mathrm{C}-9$ and $\mathrm{C}-14$ confirmed the structure of rings $\mathrm{B}$ and $\mathrm{C}$. Correlations were detected for $\mathrm{H}-15 / \mathrm{H}-16$ using ${ }^{1} \mathrm{H}^{-1} \mathrm{H}$ COSY. The HMBC correlations from $\mathrm{H}-15 / \mathrm{C}-8, \mathrm{C}-13 ; \mathrm{H}_{3}-17 / \mathrm{C}-12$, C-13 and $C-14$, suggested that $C-15$ and $C-17$ were located at $C-14$ and $C-13$, respectively. Based on these data, a novel ring A rearrangement of the pimarane diterpenoid structure was determined and named eutypenoid A, with a new carbon skeleton.

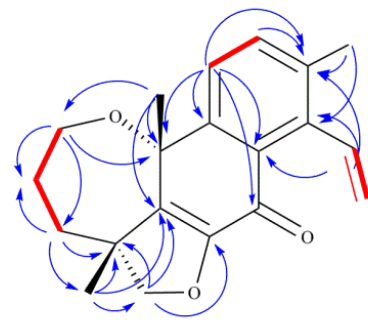

1

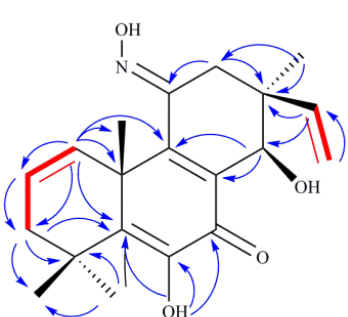

2

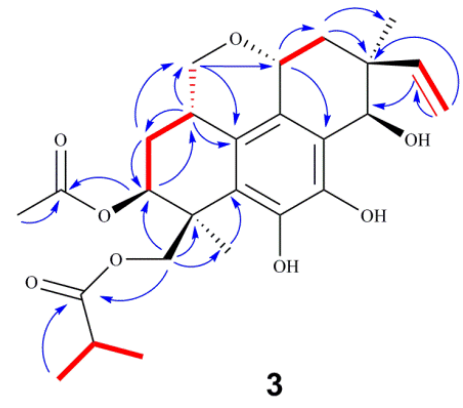

3

Figure 2. ${ }^{1} \mathrm{H}-{ }^{1} \mathrm{H}$ COSY, HMBC correlations of eutyenoids A-C (1-3). 
The relative configuration of $\mathbf{1}$ was deduced from nuclear overhauser effect spectroscopy (NOESY) analysis (Figure 3). The correlations of $\mathrm{H}-18$ with $\mathrm{H}-20$ indicated $\beta$-orientations. Finally, the proposed structure of 1 was confirmed by X-ray crystallography analysis using anomalous scattering of $\mathrm{Cu} \mathrm{K} \alpha$ radiation (Figure 4). Accordingly, the absolute configuration of $4 R, 10 R$ was established based on the value of the Flack absolute structure parameter $-0.12(10)$.

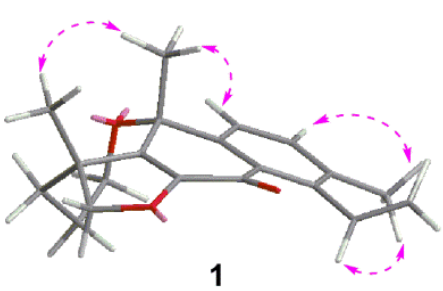

1

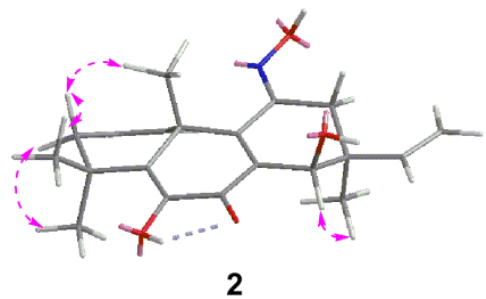

2

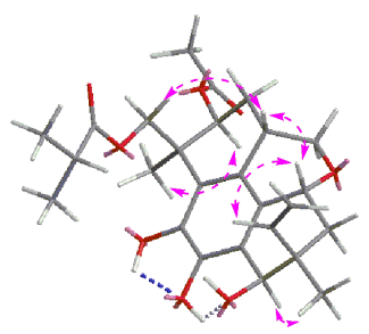

3

Figure 3. Key NOESY correlations of eutyenoids A-C (1-3).

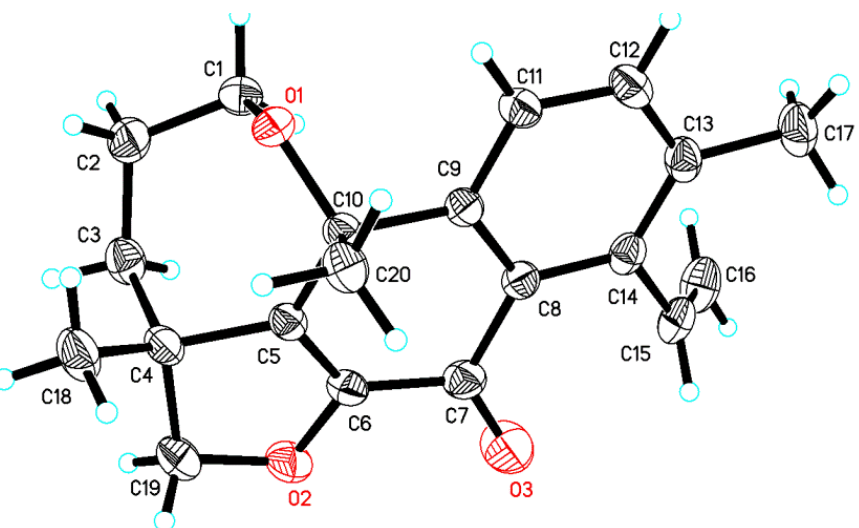

1

Figure 4. X-ray crystallographic structure of eutyenoid A (1).

Eutypenoid B (2) was isolated as a yellow powder. The HREIMS ( $m / z$ 343.1780) of 2 established a molecular formula of $\mathrm{C}_{20} \mathrm{H}_{25} \mathrm{NO}_{4}$ (calcd. 343.1784), with nine degrees of unsaturation. The ${ }^{1} \mathrm{H}$ NMR spectrum of 2 showed signals assigned to two olefinic protons $(\delta 6.15, \mathrm{dd}, J=3.3,9.5 \mathrm{~Hz} ; 6.02, \mathrm{~m})$, four methyl groups at $\delta 1.05,1.28,1.53,1.62$ (each $3 \mathrm{H}, \mathrm{s})$, and a terminal vinyl group $(\delta 5.20, \mathrm{~d}, J=18.0 \mathrm{~Hz}$, $5.17, \mathrm{~d}, J=10.8 \mathrm{~Hz} ; 6.06, \mathrm{dd}, J=18.0,10.8 \mathrm{~Hz}$ ), attached to a quaternary carbon, which is usually present in pimarane diterpenoids. The ${ }^{13} \mathrm{C}$ NMR of 2 revealed 20 carbon signals. Interpretation of the ${ }^{1} \mathrm{H}$ and ${ }^{13} \mathrm{C}$ NMR (Table 1), and HSQC spectroscopic data showed the presence of a ketone carbon $(\delta 181.3)$, a ketoxime carbon $(\delta 153.5)$, eight olefinic carbons, including one methylene and three methine, three $s p^{3}$ quaternary carbons, one oxymethine carbon, two methylene carbons, and four methyl carbons. Specifically, the HSQC did not provide the correction between the carbons and protons $(\delta 6.76, \mathrm{~s} ; 7.94, \mathrm{~s})$, which were indicative of two active hydrogens. The planar structure of 2 was established by extensive analyses of its ${ }^{1} \mathrm{H}-{ }^{1} \mathrm{H}$ COSY and HMBC spectra (Figure 2). Key HMBC correlations from $\mathrm{H}_{3}-18,19$ to $\mathrm{C}-3,5$, from $\mathrm{H}_{3}-20$ to $\mathrm{C}-1,5,9,10,11$, from $\mathrm{H}-15, \mathrm{H}_{3}-17$ to $\mathrm{C}-12,13,14$, allowed the structure of 2 to be assigned as a pimarane diterpenoid. Additionally, HMBC corrections from 6-OH to $\mathrm{C}-5,6,7$, from $\mathrm{N}-\mathrm{OH}$ to $\mathrm{C}-11$ established the enol moiety at C-6 and ketoxime moiety at $\mathrm{C}-11 .{ }^{1} \mathrm{H}-{ }^{1} \mathrm{H}$ COSY spectrum of 2 revealed the partial structure $\mathrm{H}-1$ to $\mathrm{H}-3$ via $\mathrm{H}-2$, and the connectivity between $\mathrm{H}-15$ and $\mathrm{H}-16$. The relative configuration of 2 was established from the nuclear overhauser effect (NOE) effects observed in the NOESY experiment (Figure 3). The NOE correlation revealed the relative configuration of 2 partially, in which the cross peaks of $\mathrm{H}-14 / \mathrm{H}_{3}-17$ indicated that $\mathrm{H}-14$ and 
$\mathrm{H}_{3}-17$ possessed the same orientation. The absolute configuration of 2 was established by comparison experimental and calculated electronic circular dichroism (ECD) spectra using the time-dependent density functional theory (TD-DFT) method at the B3LYP/6-31G (d,p) level in methanol with the conductor-like polarizable continuum model (CPCM), the E-isomer of ketoxime possessed the lower energy. The overall pattern of calculated ECD spectrum of $(E, 10 R, 13 S, 14 R)-2 \mathbf{b}$ was in accordance with the experimental data of $\mathbf{2}$ (Figure 5A). Therefore, the absolute configuration of $\mathbf{2}$ was established as $E$, $10 R, 13 S, 14 R$.

Table 1. ${ }^{1} \mathrm{H}$ and ${ }^{13} \mathrm{C}$ NMR data of eutypenoids $\mathrm{A}-\mathrm{C}(\mathbf{1}-\mathbf{3})$ in $\mathrm{CDCl}_{3}$.

\begin{tabular}{|c|c|c|c|c|c|c|}
\hline \multirow{2}{*}{ No. } & \multicolumn{2}{|r|}{1} & \multicolumn{2}{|r|}{2} & \multicolumn{2}{|r|}{3} \\
\hline & $\delta_{\mathrm{C}}{ }^{\mathrm{a}}$ & $\delta_{\mathbf{H}} \mathbf{b}(J$ in $\mathrm{Hz})$ & $\delta_{\mathrm{C}}{ }^{\mathrm{c}}$ & $\delta_{\mathrm{H}}^{\mathrm{d}}(J$ in $\mathrm{Hz})$ & $\delta_{\mathrm{C}}{ }^{\mathrm{a}}$ & $\delta_{\mathrm{H}} \mathbf{b}(J$ in $\mathrm{Hz})$ \\
\hline 1 & $67.2, \mathrm{CH}_{2}$ & $\begin{array}{l}3.71, \mathrm{~d}(13.1) \\
2.90, \mathrm{t}(12.3)\end{array}$ & $132.2, \mathrm{CH}$ & $6.15, \mathrm{dd}(3.3,9.5)$ & $28.7, \mathrm{CH}$ & $2.88, \mathrm{~m}$ \\
\hline 2 & 27.6, $\mathrm{CH}_{2}$ & $\begin{array}{l}1.97, \mathrm{~m} \\
1.58, \mathrm{~m}\end{array}$ & $127.8, \mathrm{CH}$ & $6.02, \mathrm{~m}$ & $25.7, \mathrm{CH}_{2}$ & $2.15, \mathrm{~m} 1.45, \mathrm{~m}$ \\
\hline 3 & $40.6, \mathrm{CH}_{2}$ & $1.66, \mathrm{~m}$ & $39.6, \mathrm{CH}_{2}$ & $\begin{array}{c}2.47, \mathrm{~d}(16.0) \\
2.05, \mathrm{dd}(7.7,16.0)\end{array}$ & $72.8, \mathrm{CH}$ & $5.20, \mathrm{~d}(2.7)$ \\
\hline 4 & $49.8, \mathrm{C}$ & & $38.3, \mathrm{C}$ & & $41.3, \mathrm{C}$ & \\
\hline 5 & $138.6, \mathrm{C}$ & & 146.6, C & & 122.7, C & \\
\hline 6 & 149.3, C & & 143.0, C & & 143.3, C & \\
\hline 7 & 179.0, C & & 181.3, C & & $142.3, \mathrm{C}$ & \\
\hline 8 & $129.6, \mathrm{C}$ & & 133.6, C & & $119.2, \mathrm{C}$ & \\
\hline 9 & $148.8, \mathrm{C}$ & & 153.0, C & & 124.7, C & \\
\hline 10 & $76.9, \mathrm{C}$ & & $44.8, \mathrm{C}$ & & $126.2, \mathrm{C}$ & \\
\hline 11 & $124.1, \mathrm{CH}$ & $7.54, \mathrm{~d}(8.0)$ & $153.5, \mathrm{C}$ & & $66.5, \mathrm{CH}$ & $4.60, \mathrm{dd}(6.2,10.6)$ \\
\hline 12 & 135.0, CH & $7.43, \mathrm{~d}(8.0)$ & 28.7, $\mathrm{CH}_{2}$ & $2.86, \mathrm{~s}$ & 42.6, $\mathrm{CH}_{2}$ & $2.18, \mathrm{~m} 1.72, \mathrm{~m}$ \\
\hline 13 & $136.5, \mathrm{C}$ & & $39.7, \mathrm{C}$ & & 43.3, C & \\
\hline 14 & $140.6, \mathrm{C}$ & & $69.8, \mathrm{CH}$ & $4.68, \mathrm{~s}$ & $76.5, \mathrm{CH}$ & $4.82, \mathrm{~s}$ \\
\hline 15 & $137.1, \mathrm{CH}$ & $7.19, \mathrm{dd}(11.5,18.0)$ & $142.4, \mathrm{CH}$ & $6.06, \mathrm{dd}(18.0,10.8)$ & $138.2, \mathrm{CH}$ & $5.92, \mathrm{dd}(10.7,17.7)$ \\
\hline 16 & 117.0, $\mathrm{CH}_{2}$ & $\begin{array}{l}5.49, \mathrm{~d}(11.5) \\
5.06, \mathrm{~d}(18.0)\end{array}$ & $114.4, \mathrm{CH}_{2}$ & $\begin{array}{l}5.20, \mathrm{~d}(18.0) \\
5.17, \mathrm{~d}(10.8)\end{array}$ & $119.8, \mathrm{CH}_{2}$ & $\begin{array}{l}5.36, \mathrm{~d}(10.7) \\
5.33, \mathrm{~d}(17.7)\end{array}$ \\
\hline 17 & $21.4, \mathrm{CH}_{3}$ & $2.37, \mathrm{~s}$ & $23.9, \mathrm{CH}_{3}$ & $1.05, \mathrm{~s}$ & $23.5, \mathrm{CH}_{3}$ & $1.31, \mathrm{~s}$ \\
\hline 18 & $20.1, \mathrm{CH}_{3}$ & $1.47, \mathrm{~s}$ & 27.9, $\mathrm{CH}_{3}$ & $1.28, \mathrm{~s}$ & $66.3, \mathrm{CH}_{2}$ & $\begin{array}{l}5.16, \mathrm{~d}(10.7) \\
4.31, \mathrm{~d}(10.7)\end{array}$ \\
\hline 19 & 83.4, $\mathrm{CH}_{2}$ & $\begin{array}{l}4.22, \mathrm{~d}(8.6) \\
4.11, \mathrm{~d}(8.6)\end{array}$ & $27.4, \mathrm{CH}_{3}$ & $1.53, \mathrm{~s}$ & $22.1, \mathrm{CH}_{3}$ & $1.45, \mathrm{~s}$ \\
\hline 20 & $33.1, \mathrm{CH}_{3}$ & $1.60, \mathrm{~s}$ & $27.0, \mathrm{CH}_{3}$ & $1.62, \mathrm{~s}$ & 68.6, $\mathrm{CH}_{2}$ & $\begin{array}{c}4.05, \mathrm{dd}(6.5,8.9) \\
3.10, \mathrm{dd}(8.9,10.8) \\
\end{array}$ \\
\hline $6-\mathrm{OH} / 21$ & & & & $6.76, \mathrm{~s}$ & $170.6, \mathrm{C}$ & \\
\hline $\mathrm{N}-\mathrm{OH} / 22$ & & & & $7.94, \mathrm{~s}$ & $21.4, \mathrm{CH}_{3}$ & $1.97, \mathrm{~s}$ \\
\hline 23 & & & & & 177.1, C & \\
\hline 24 & & & & & $34.4, \mathrm{CH}$ & 2.53, sep $(7.0)$ \\
\hline 25 & & & & & $19.1, \mathrm{CH}_{3}$ & $1.14, \mathrm{~d}(7.0)$ \\
\hline 26 & & & & & $19.2, \mathrm{CH}_{3}$ & $1.12, \mathrm{~d}(7.0)$ \\
\hline
\end{tabular}

Eutypenoid C (3) was afforded as a yellow powder. The molecular formula was determined to be $\mathrm{C}_{26} \mathrm{H}_{34} \mathrm{O}_{8}$ with 10 degrees of unsaturation, based on HRESIMS $(\mathrm{m} / z \text { 497.2143 [M }+\mathrm{Na}]^{+}$, calcd. for $\mathrm{C}_{26} \mathrm{H}_{34} \mathrm{O}_{8} \mathrm{Na}$, 497.2146). NMR spectroscopic data of 3 (Table 1) showed the presence of the acetyl $(\delta 170.6(\mathrm{~d}), 21.4(\mathrm{~s}))$ and an isobutyryl $(\delta 177.1(\mathrm{~d}), 34.4(\mathrm{t}), 19.2(\mathrm{~s}), 19.1(\mathrm{~s}))$. In addition to these two substituents, the ${ }^{1} \mathrm{H}$ NMR spectrum of 3 also exhibited the characteristic pattern for a terminal vinyl 
group $(\delta 5.33, \mathrm{~d}, J=17.7 \mathrm{~Hz}, 5.36, \mathrm{~d}, J=10.7 \mathrm{~Hz} ; 5.92, \mathrm{dd}, J=17.7 / 10.7 \mathrm{~Hz})$, the ${ }^{13} \mathrm{C}$ NMR spectrum of 3 in combination with HSQC data revealed two methyls and eight olefinic carbons. These data suggested that compound 3 is a disubstituted tetracyclic pimarane diterpenoid. The basic carbon skeleton of 3 was established by comprehensive analysis of the 2D NMR spectroscopic data, particularly the ${ }^{1} \mathrm{H}-{ }^{1} \mathrm{H}$ COSY and HMBC correlations (Figure 2). Correlations were detected for $\mathrm{H}_{2}-20 / \mathrm{H}-1 / \mathrm{H}-2 / \mathrm{H}-3$ by COSY, indicating C-20 was attached to C-1, the HMBC correlations from $\mathrm{H}_{2}-20$ to $\mathrm{C}-1, \mathrm{C}-2, \mathrm{C}-10, \mathrm{C}-11$, and from $\mathrm{H}-11$ to $\mathrm{C}-8, \mathrm{C}-9$, indicating a pyranoid ring was formed through $\mathrm{C}-20 / \mathrm{C}-1 / \mathrm{C}-10 / \mathrm{C}-9 / \mathrm{C}-11$. The acetylated and isobutyrylated positions were determined to be C-3 and C-19 based on the HMBC correlations from $\mathrm{H}-3$ to $\delta 170.6$, and from $\mathrm{H}-19$ to $\delta 177.1$, respectively. The relative configuration of 3 was established using NOESY (Figure 3). The correlations of $\mathrm{H}-11$ with $\mathrm{H}-15$, of $\mathrm{H}-11$ with $\mathrm{H}-1$, of $\mathrm{H}-1$ with $\mathrm{H}_{2}-19$ indicated $\beta$-orientations, the correlation of $\mathrm{H}-17$ with $\mathrm{H}-14$, of $\mathrm{H}-3$ with $\mathrm{H}-18$ indicated $\alpha$-orientations. TD-DFT ECD calculations of $\mathbf{3} \mathbf{a}$ and $\mathbf{3} \mathbf{b}$ were performed (Figure $5 \mathrm{~B}$ ), followed by comparison of experimental and calculational ECD spectra. The best agreement occurred between the experimental ECD curve and the calculated one for $(1 S, 3 S, 4 S, 11 R, 13 S, 14 R)-3 \mathbf{b}$, indicating the absolute configuration of 3 as $1 S, 3 S, 4 S, 11 R, 13 S, 14 R$.
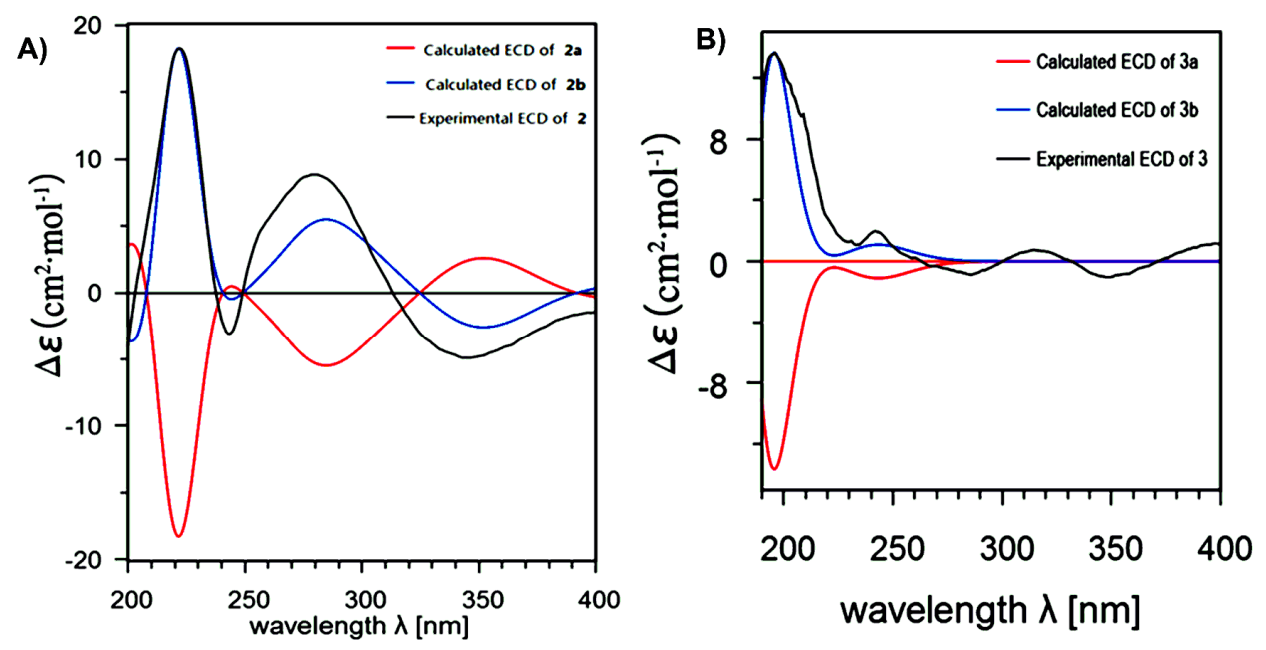

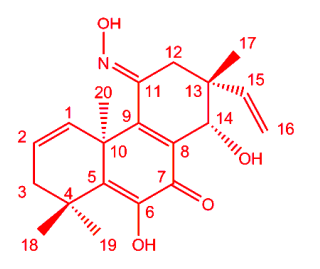

2a

$[E, 10 S, 13 R, 14 S]$

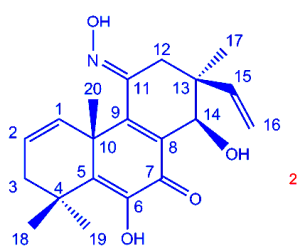

2b

$[E, 10 R, 13 S, 14 R]$

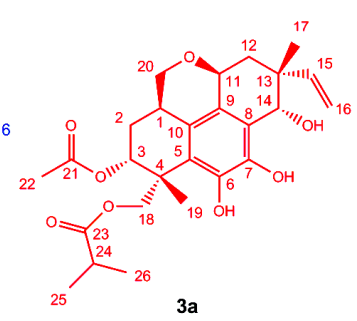

$[1 R, 3 R, 4 R, 11 S, 13 R, 14 S]$

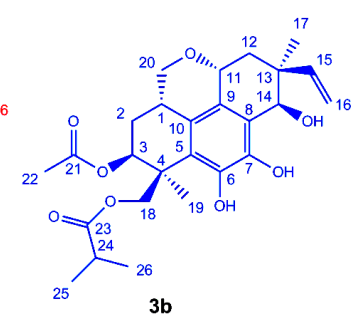

$[1 S, 3 S, 4 S, 11 R, 13 S, 14 R]$

Figure 5. Comparison of experimental and calculated ECD spectra of 2 (A) and 3 (B). Geometries optimization were performed at theB3LYP/6-31G(d) level and ECD calculation were performed at the B3LYP/6-31G(d,p) level in methanol with the CPCM model.

Pimarane diterpenoids with anti-inflammtory effects have been reported $[17,18]$. In our bioassay of eutypenoids A-C with several anti-inflammatory models, we found that eutypenoid B (2) had an immunosuppressive effect. The immunosuppressive effects of eutypenoids A-C (1-3) were examined on splenocyte proliferation induced by concanavalin A (ConA) using a method described in the literature [19]. The results showed that compounds $1-3$ had no cytotoxic effect on splenocytes at concentrations from $1.6 \mu \mathrm{mol}$ to $40 \mu \mathrm{mol}$. Within the concentration range, eutypenoid B (2) exhibited significant inhibition of splenocyte proliferation under ConA induction, while eutypenoids $\mathrm{A}$ and $\mathrm{C}$ has no significant effects (Figure 6). Our findings, from an antiproliferation assay, propose that compound 2, not only has no cytotoxic effect on splenocytes, but exhibited significant inhibition of 
splenocyte proliferation under ConA induction. Further study is needed to confirm the effect and pursue the mechanisms of action.

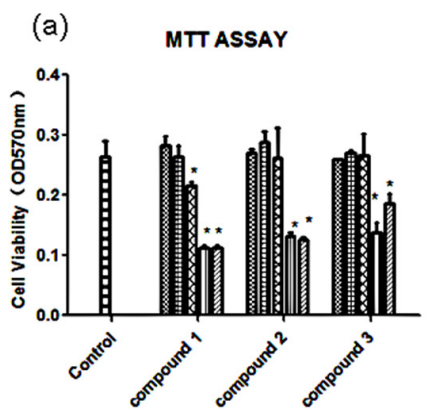

(a)

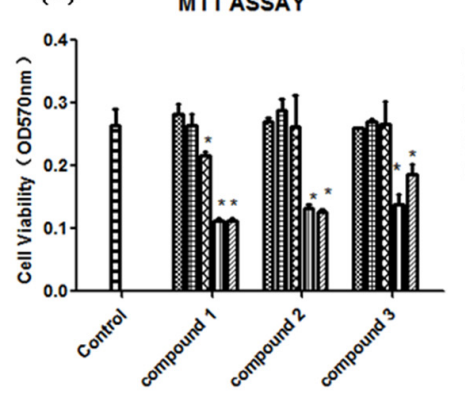

(b)
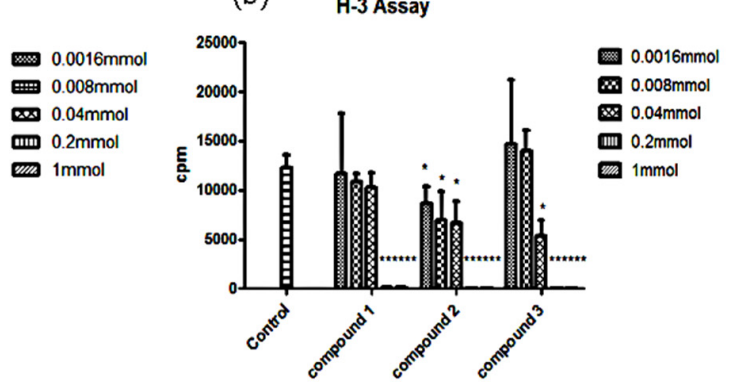

(b)
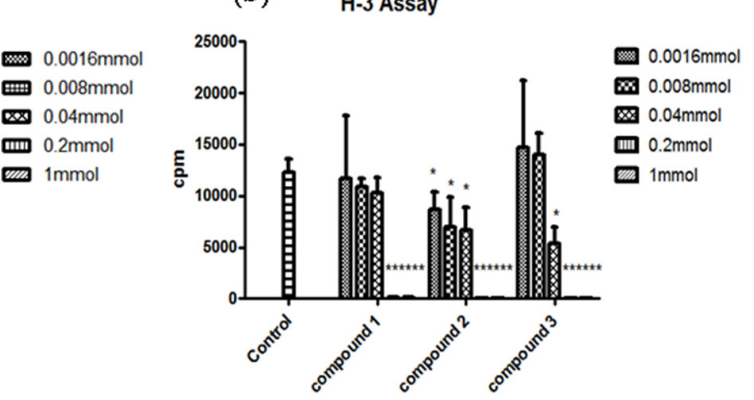

Figure 6. Cytotoxicity on splenocytes and inhibition on ConA-induced splenocyte proliferation of compounds 1-3. (a) Cytotoxicity of compounds 1-3 on BALB/c mice splenocytes. The cells were incubated with different concentration of compounds 1-3 for $48 \mathrm{~h}$. MTT was then added to the medium $(0.5 \mathrm{mg} / \mathrm{mL})$ and incubated for $4 \mathrm{~h}$ before the end of the incubation period. The cell viability was tested through the relative formazan concentration measured by the optical density at $570 \mathrm{~nm}$ (OD570 nm) using a microplate reader. (b) Inhibition of compounds 1-3 on ConA-induced splenocyte proliferation. BALB/c mice splenocytes $\left(4 \times 10^{5}\right.$ cells/well) were stimulated by ConA $(2 \mu \mathrm{g} / \mathrm{mL})$ for $48 \mathrm{~h}$ in the presence of different compounds 1-3. Cells were then pulsed with $0.25 \mu \mathrm{Ci}\left[{ }^{3} \mathrm{H}\right]$-thymidine $8 \mathrm{~h}$ before the end of the experiment and were assessed for $\left[{ }^{3} \mathrm{H}\right]$-thymidine incorporation by counts per minute (cpm). Results are mean \pm S.D. $* p<0.05, * * p<0.01$, treatment group versus control.

\section{Experimental Section}

\subsection{General Experimental Procedures}

Optical rotations were determined using a Perkin-Elmer 341 polarimeter. CD spectra were obtained on a Chirascan spectrometer (Applied Photophysics Ltd., Leatherhead, UK). The NMR spectra were recorded on a Bruker AM-400 spectrometer at $400 \mathrm{MHz}$ for ${ }^{1} \mathrm{H}$ and $100 \mathrm{MHz}$ for ${ }^{13} \mathrm{C}$ in $\mathrm{CDCl}_{3}$ or Bruker AVANCE-III instrument operating at $600 \mathrm{MHz}$ for ${ }^{1} \mathrm{H}$ and $150 \mathrm{MHz}$ for ${ }^{13} \mathrm{C}$. ECD spectra were recorded in EtOH with a Chirascan CD spectrometer. ESIMS and HRESIMS were obtained using an Esquire 3000 plus and a Q-TOF-Ultima mass spectrometer, respectively. Silica gel (200 mesh to 300 mesh, Qingdao Haiyang Chemical Co., Ltd., Qingdao, China), $C_{18}$ reversed phase silica gel (150 to 200 mesh, Fuji Silysia Chemical, Ltd., Aichi, Japan), MCI gel (CHP20P, $75 \mu \mathrm{m}$ to $150 \mu \mathrm{m}$, Mitsubishi Chemical Industries, Ltd., Tokyo, Japan), and Sephadex LH-20 gel (Pharmacia Biotech AB, Uppsala, Sweden) were used for column chromatography (CC). High performance liquid chromatography was performed on an Angilent 1200 HPLC apparatus with an Eclipse XDB-C 18 column $(250 \times 9.4 \mathrm{~mm}, 5 \mu \mathrm{m})$.

\subsection{Fungal Strain}

The fungus was isolated from the soil of London Island of Kongsfjorden of Ny-lesund District (altitude of $100 \mathrm{~m}$ ) in the Arctic. It was isolated in potato dextrose agar (PDA) medium with incubation 
at $20^{\circ} \mathrm{C}$. Due to its chemical and morphological features, as well as the $18 \mathrm{~S}$ rDNA (GenBank accession No. FJ430580), the strain was assigned to the genus Eutypella. The strain was deposited in PDA medium with the Second Military Medical University, Xiangyin Road 800, 200433, Shanghai, P. R. China. Eutypella sp. D-1 was cultured in potato dextrose broth (PDB; potato $1 \%$, glucose $2 \%$, dist. $\mathrm{H}_{2} \mathrm{O}$ $1000 \mathrm{~mL})$.

\subsection{Culture Condition}

The fungus was maintained in PDA medium at $20{ }^{\circ} \mathrm{C}$ for 7 days, and then three pieces $\left(0.5 \times 0.5 \mathrm{~cm}^{2}\right)$ of mycelial agar plugs were inoculated into $60 \times 250 \mathrm{~mL}$ Erlenmeyer flasks, each containing $70 \mathrm{~mL}$ of PDB. After $5 \mathrm{~d}$ of incubation at $20{ }^{\circ} \mathrm{C}$ on a rotary shaker at $180 \mathrm{rpm}, 70 \mathrm{~mL}$ of seed cultures were transferred into a total of 250 flasks $(2.0 \mathrm{~L})$ containing $700 \mathrm{~mL}$ of PDB. The liquid cultivation that followed was kept for 9 days at $20^{\circ} \mathrm{C}$ and $180 \mathrm{rpm}$ on a rotary shaker.

\subsection{Extraction and Isolation}

The culture (150 L) was centrifuged to give the broth and mycelia. The broth was exhaustively extracted with EtOAc three times, then the EtOAc layers were combined and evaporated under reduced pressure at a temperature not exceeding $40{ }^{\circ} \mathrm{C}$ to yield a dark brown gum (200 g), which was subjected to column chromatography on silica gel and eluted with EtOH in petroleum ether (PE) (0\%-100\%, stepwise) to yield 5 fractions (Fr. 1-Fr. 5). Fr. 3 (30 g) was subjected to CC by using EtOAc in PE (0\%-100\%, stepwise) to yield 4 fractions (Fr. 3A-Fr. 3D). Fr. 3A was further purified by Sephadex LH-20 using $\mathrm{MeOH}$ and then finally by semi-preparative $\mathrm{HPLC}\left(58: 42 \mathrm{CH}_{3} \mathrm{CN}-\mathrm{H}_{2} \mathrm{O} ; 3.0 \mathrm{~mL} / \mathrm{min}\right)$ to give compound $2\left(13 \mathrm{mg}, t_{\mathrm{R}}=7.9 \mathrm{~min}\right)$. Fr. 3C was separated using CC of ODS with a MeOH gradient $(10 \%-100 \%)$ in $\mathrm{H}_{2} \mathrm{O}$ to yield 12 fractions (Fr. 3CI-Fr. 3CXII). Fr. 3CVIII was separated by reversed-phase $\mathrm{HPLC}\left(50: 50 \mathrm{CH}_{3} \mathrm{CN}-\mathrm{H}_{2} \mathrm{O} ; 3.0 \mathrm{~mL} / \mathrm{min}\right)$ to give compound $1\left(3 \mathrm{mg}, t_{\mathrm{R}}=17.0 \mathrm{~min}\right)$. Fr. 3CIX was separated by reversed-phase $\mathrm{HPLC}\left(58: 42 \mathrm{CH}_{3} \mathrm{CN}-\mathrm{H}_{2} \mathrm{O} ; 3.0 \mathrm{~mL} / \mathrm{min}\right)$ to give compound $3\left(4 \mathrm{mg}, t_{\mathrm{R}}=27.1 \mathrm{~min}\right)$.

Eutypenoid A (1): colorless needle crystals; $[\alpha]_{\mathrm{D}}^{25}=-8.0^{\circ}$ (c 0.05, MeOH); $\mathrm{CD}(\mathrm{MeOH}) \Delta \varepsilon(\mathrm{nm}):-9.6$ (196), 5.3 (224), 9.0 (272), 3.8 (335), -4.2 (375); UV (MeOH) $\lambda_{\max }: 319 \mathrm{~nm}, 266 \mathrm{~nm}, 217 \mathrm{~nm} ;{ }^{13} \mathrm{C}$ and ${ }^{1} \mathrm{H}$ NMR data (400 MHz; $\mathrm{CDCl}_{3}$ ), see Table 1; HREIMS m/z $310.1570 \mathrm{M}^{+}$(calcd. for $\mathrm{C}_{20} \mathrm{H}_{22} \mathrm{O}_{3}, 310.1569$ ).

A suitable colorless crystal $\left(0.25 \times 0.2 \times 0.12 \mathrm{~mm}^{3}\right)$ of 1 was grown by slow evaporation from an acetone solution. Diffraction intensity data were acquired with a Bruker APEX-II CCD area detector with graphite monochromated $\mathrm{Cu} \mathrm{K} \alpha$ radiation $(\lambda=1.54178 \AA)$. Crystal data for $1: \mathrm{C}_{20} \mathrm{H}_{22} \mathrm{O}_{3}$ (formula weight 310.37), orthorhombic, space group, $\mathrm{P} 2{ }_{1} 2_{1} 2_{1}(\# 113), \mathrm{T}=296(2) \mathrm{K}, \mathrm{a}=7.55310(10) \AA$, $\mathrm{b}=11.8579$ (2) $\AA, \mathrm{c}=18.1930$ (3) $\AA, \mathrm{V}=1629.44(4) \AA^{3}, \mathrm{D}_{\mathrm{c}}=1.265 \mathrm{Mg} / \mathrm{m}^{3}, \mathrm{Z}=4, \mathrm{~F}(000)=664, \mu(\mathrm{Cu}$ $\mathrm{K} \alpha)=0.669 \mathrm{~mm}^{-1}$. A total of 9465 reflections were collected in the range $4.451^{\circ}<\theta<69.681^{\circ}$, with 2900 independent reflections $(R(\mathrm{int})=0.0407)$; completeness to $\theta_{\max }$ was $99.8 \%$; semi empirical from equivalents 0.7533 and 0.6097 ; full matrix least squares refinement on $\mathrm{F}^{2}$; the number of data/restraints/parameters were 2900/0/212; goodness of fit on $\mathrm{F}^{2}=1.044$; final $R$ indices $[I>2 \sigma(I)]$, $R_{1}=0.0332 w R_{2}=0.0907 ; R$ indices (all data), $R_{1}=0.0342, w R_{2}=0.0918$, largest difference peak and hole, 0.123 and $-0.114 \mathrm{e} / \AA^{3}$. Flack parameter $=-0.12(10)$. Crystallographic data for the structure of 1 have been deposited at the Cambridge Crystallographic Data Centre under the reference number CCDC 1439456.

Eutypenoid B (2): yellow powder; $[\alpha]_{\mathrm{D}}^{25}=-16.0^{\circ}$ (c 0.05, MeOH); $\mathrm{CD}(\mathrm{MeOH}) \Delta \varepsilon(\mathrm{nm}): 18.3(222)$, -3.1 (243), 8.8 (280), -4.9 (346); UV (MeOH) $\lambda_{\max }: 328 \mathrm{~nm}, 288 \mathrm{~nm}, 241 \mathrm{~nm} ;{ }^{13} \mathrm{C}$ and ${ }^{1} \mathrm{H}$ NMR data (400 MHz; $\mathrm{CDCl}_{3}$ ), see Table 1; HREIMS m/z $343.1780 \mathrm{M}^{+}$(calcd. for $\mathrm{C}_{20} \mathrm{H}_{25} \mathrm{NO}_{4}, 343.1784$ ).

Eutypenoid C (3): yellow powder; $[\alpha]_{\mathrm{D}}^{25}=-12.0^{\circ}$ (c 0.05, MeOH); CD (MeOH) $\Delta \varepsilon$ (nm): 13.6 (196), 2.0 (242), -0.8 (286), 0.7 (314), 1.0 (346); UV (MeOH) $\lambda_{\max }: 288 \mathrm{~nm}, 235 \mathrm{~nm} ;{ }^{13} \mathrm{C}$ and ${ }^{1} \mathrm{H}$ NMR data (400 MHz; $\mathrm{CDCl}_{3}$ ), see Table 1; HRESIMS m/z 497.2143 [M + Na] ${ }^{+}$(calcd. for $\mathrm{C}_{26} \mathrm{H}_{34} \mathrm{O}_{8} \mathrm{Na}$, 497.2146). 


\subsection{Material and Method}

Electronic circular dichroism (ECD) spectrum, associated ab initio (TD) DFT calculations, is a reliable spectroscopic tool for determining the absolute configuration of chiral compounds [20,21]. Firstly, conformation searches were carried out using a conformational search module in Schrodinger, with the OPLS_2005 Force field and the torsional sampling (MCMM) method. Then, the conformers were optimized using the DFT calculation. Frequency calculations were also performed to confirm that the geometries obtained correspond to energetic minima. The geometries of the optimized conformers were provided in the Supporting Information. Calculation of ECD spectra were performed using the TDDFT calculation. The ECD spectra were obtained by weighing the Boltzmann distribution rate of each conformer with the software SpecDis1.62 [22].

\subsection{Antiproliferation Assay}

Cell viability was assessed by performing an MTT assay [17]. In brief, splenocytes $\left(4 \times 10^{5}\right.$ cells/well) were cultured in triplicate with or without compounds $1-3$ in a 96 well plate at $37^{\circ} \mathrm{C}$ in a $5 \% \mathrm{CO}_{2}$ atmosphere for $48 \mathrm{~h}$. MTT was then added to the medium $(0.5 \mathrm{mg} / \mathrm{mL})$ and incubated for $4 \mathrm{~h}$ before the end of the incubation period. The medium was removed, and the cells were diluted in dimethyl sulphoxide. The relative formazan concentration was measured by the optical density at $570 \mathrm{~nm}$ (OD570 nm) using a microplate reader (BioTek, PowWave XS2, Winooski, VT, USA). Compounds 1-3 did not react with MTT. Splenic lymphocytes $\left(4 \times 10^{5}\right.$ cells/well $)$ and compounds 1-3 in 96 well plates were cultured in triplicate for $48 \mathrm{~h}$ by using ConA $(2 \mu \mathrm{g} / \mathrm{mL})$. The cells were pulsed at $0.25 \mu \mathrm{Ci}$ /well of $\left[{ }^{3} \mathrm{H}\right]$-thymidine for $8 \mathrm{~h}$ before the end of the culture period, and then harvested onto glass fiber filters. $\left[{ }^{3} \mathrm{H}\right]$-thymidine incorporation was measured by counts per minute (cpm) using a beta scintillation counter (MicroBeta Trilux, PerkinElmer Life Sciences, Boston, MA, USA).

\section{Conclusions}

In conclusion, through the chemical investigation of Eutypella sp. D-1 from the Arctic, Eutypenoid B (2) a pimarane diterpenoid alkaloid was firstly isolated from natural metabolites, Eutypenoids A and $\mathrm{C}$ (1 and 3) were two unusual ring A rearranged pimarane diterpenoids with a new carbon skeleton, respectively. Among of them, Eutypenoid B (2) exhibited potent immunosuppressive activities.

Acknowledgments: The project was financially supported by the National High Technology Research and Development Program of China (863 program) (2013AA093003), the Program for Professors of Special Appointment (Eastern Scholar) in the Shanghai Institutions of Higher Learning (2012-90) and the National Natural Science Foundation of China (81173518, 81261120567).

Author Contributions: Yi-Ming Li and Xiao-Yu Liu designed the experiment and contributed to structure elucidation and manuscript preparation. Liu-Qiang Zhang, Xiao-Chong Chen, and Kai-Xian Chen carried out the experiment and wrote the manuscript. Zhao-Qiang Chen and Gui-Min Wang carried out the calculations of ECD spectra. Shi-Guo Zhu and Yi-Fu Yang performed the bioassays.

Conflicts of Interest: The authors declare no conflicts of interest.

\section{References}

1. Blunt, J.W.; Copp, B.R.; Keyzers, R.A.; Munro, M.H.G.; Prinsep, M.R. Marine natural products. Nat. Prod. Rep. 2013, 30, 237-323. [CrossRef] [PubMed]

2. Blunt, J.W.; Copp, B.R.; Keyzers, R.A.; Munro, M.H.G.; Prinsep, M.R. Marine natural products. Nat. Prod. Rep. 2014, 31, 160-258. [CrossRef] [PubMed]

3. Blunt, J.W.; Copp, B.R.; Keyzers, R.A.; Munro, M.H.G.; Prinsep, M.R. Marine natural products. Nat. Prod. Rep. 2015, 32, 116-211. [CrossRef] [PubMed]

4. Timling, I.; Walker, D.A.; Nusbaum, C.; Lennon, N.J;; Taylor, D.L. Rich and cold: Diversity, distribution and drivers of fungal communities in patterned-ground ecosystems of the North American Arctic. Mol. Ecol. 2014, 23, 3258-3272. [CrossRef] [PubMed] 
5. Pongcharoen, W.; Rukachaisirikul, V.; Phongpaichit, S.; Rungjindamai, N.; Sakayaroj, J. Pimarane diterpene and cytochalasin derivatives from the endophytic fungus Eutypella scoparia PSU-D44. J. Nat. Prod. 2006, 69, 856-858. [CrossRef] [PubMed]

6. Ciavatta, M.L.; Lopez-Gresa, M.P.; Gavagnin, M.; Nicoletti, R.; Manzo, E.; Mollo, E.; Guo, Y.W.; Cimino, G. Cytosporin-related compounds from the marine-derived fungus Eutypella scoparia. Tetrahedron 2008, 64, 5365-5369. [CrossRef]

7. Isaka, M.; Palasarn, S.; Lapanun, S.; Chanthaket, R.; Boonyuen, N.; Lumyong, S. $\gamma$-Lactones and ent-eudesmane sesquiterpenes from the endophytic fungus Eutypella sp. BCC 13199. J. Nat. Prod. 2009, 72, 1720-1722. [CrossRef] [PubMed]

8. Isaka, M.; Palasarn, S.; Prathumpai, W.; Laksancharoen, P. Pimarane diterpene from the endophytic fungus Eutypella sp. BCC 13199. Chem. Pharm. Bull. 2011, 59, 1157-1159. [CrossRef] [PubMed]

9. Sun, L.; Li, D.L.; Chen, Y.C.; Tao, M.H.; Zhang, W.M.; Dan, F.J. Purification, identification and antitumor activities of secondarymetabolites from marine fungus Eutypella scoparia FS26. Mycosystema 2011, 30, 268-274.

10. Sun, L.; Li, D.L.; Tao, M.H.; Dan, F.J.; Zhang, W.M. Two new sesquiterpenes from the marine fungus Eutypella scoparia FS26 from the South China Sea. Helv. Chim. Acta 2012, 95, 157-162. [CrossRef]

11. Sun, L.; Li, D.L.; Tao, M.H.; Chen, Y.C.; Dan, F.J.; Zhang, W.M. Scopararanes C-G: New oxygenated pimarane diterpenes from the marine sediment-derived fungus Eutypella scoparia FS26. Mar. Drugs 2012, 10, 539-550. [CrossRef] [PubMed]

12. Sun, L.; Li, D.L.; Tao, M.H.; Chen, Y.C.; Zhang, Q.B.; Dan, F.J.; Zhang, W.M. Two new polyketides from a marine sediment-derived fungus Eutypella scoparia FS26. Nat. Prod. Res. 2013, 127, 1298-1304. [CrossRef] [PubMed]

13. Kongprapan, T.; Rukachaisirikul, V.; Saithong, S.; Phongpaichit, S.; Poonsuwan, W.; Sakayaroj, J. Cytotoxic cytochalasins from the endophytic fungus Eutypella scoparia PSU-H267. Phytochem. Lett. 2015, 13, 171-176. [CrossRef]

14. Lu, X.L.; Liu, J.T.; Liu, X.Y.; Gao, Y.; Zhang, J.P.; Jiao, B.H.; Zheng, H. Pimarane diterpenes from the Arctic fungus Eutypella sp. D-1. J. Antibiot. 2014, 67, 171-174. [CrossRef] [PubMed]

15. Liu, J.T.; Hu, B.; Gao, Y.; Zhang, J.P.; Jiao, B.H.; Lu, X.L.; Liu, X.Y. Bioactive tyrosine-derived cytochalasins from Fungus Eutypella sp. D-1. Chem. Biodivers. 2014, 11, 800-806. [CrossRef] [PubMed]

16. Liu, X.Y.; Chen, X.C.; Qian, F.; Zhu, T.T.; Xu, J.W.; Li, Y.M.; Zhang, L.Q.; Jiao, B.H. Chlorinated phenolic sesquiterpenoids from the Arctic fungus Nectria sp. B-13. Biochem. Syst. Ecol. 2015, 59, 22-25. [CrossRef]

17. Cho, J.G.; Cha, B.J.; Min Lee, S.; Shrestha, S.; Jeong, R.H.; Sung Lee, D.; Kim, Y.C.; Lee, D.G.; Kang, H.C.; Kim, J.; et al. Diterpenes from the roots of Oryza sativa L. and their inhibition activity on NO production in LPS-stimulated RAW264.7 macrophages. Chem. Biodivers. 2015, 12, 1356-1364. [CrossRef] [PubMed]

18. Wu, Z.Y.; Zhang, Y.B.; Zhu, K.K.; Luo, C.; Zhang, J.X.; Cheng, C.R.; Feng, R.H.; Yang, W.Z.; Zeng, F.; Wang, Y.; et al. Anti-inflammatory diterpenoids from the root bark of Acanthopanax gracilistylus. J. Nat. Prod. 2014, 77, 2342-2351. [CrossRef] [PubMed]

19. Feng, Y.H.; Zhu, Y.N.; Liu, J.; Ren, Y.X.; Xu, J.Y.; Yang, Y.F.; Li, X.Y.; Zou, J.P. Differential regulation of resveratrol on lipopolysacchride-stimulated human macrophages with or without IFN-gamma pre-priming. Int. Immunopharmacol. 2004, 4, 713-720. [CrossRef] [PubMed]

20. Berova, N.; Di Bari, L.; Pescitelli, G. Application of electronic circular dichroism in configurational and conformational analysis of organic compounds. Chem. Soc. Rev. 2007, 36, 914-931. [CrossRef] [PubMed]

21. Miao, F.P.; Liang, X.R.; Yin, X.L.; Wang, G.; Ji, N.Y. Absolute configurations of unique harziane diterpenes from Trichoderma species. Org. Lett. 2012, 14, 3815-3817. [CrossRef] [PubMed]

22. Bruhn, T.; Schaumloffel, A.; Hemberger, Y.; Bringmann, G. SpecDis: Quantifying the comparison of calculated and experimental electronic circular dichroism spectra. Chirality 2013, 25, 243-249. [CrossRef] [PubMed]

(C) 2016 by the authors; licensee MDPI, Basel, Switzerland. This article is an open access article distributed under the terms and conditions of the Creative Commons by Attribution (CC-BY) license (http://creativecommons.org/licenses/by/4.0/). 